has lost six similar cases so far, and hundreds more are pending (Cronin Fisk and Whittington 2010).

Rice futures prices eventually recovered, as energy costs and commodity speculation drove bidding to record highs in 2008. But LibertyLink was detected in subsequent shipments, preventing marketers from taking advantage of high prices and effectively restricting U.S. ride trade with the European Union (GAO 2008). California rice growers were largely unaffected by the LibertyLink incident, because they primarily grow short- and medium-grain rice (table 1). Only one
TABLE 1. Regulatory status and field-test locations for Bayer's LibertyLink (LL) rice

\begin{tabular}{|c|c|c|c|c|}
\hline Variety & Grain type & Federal regulatory status* & Calif. certification status $†$ & Field-trial locations \\
\hline LL62 & Medium & Approved 1999 & $\begin{array}{l}\text { Approved for greenhouse } \\
\text { trial in } 2008\end{array}$ & La. (2); Puerto Rico (2); Calif. \\
\hline LL06 & Medium & Approved 1999 & Not approved & Calif. (10); Puerto Rico (2) \\
\hline LL601 & Long & Approved 2006‡ & Not approved & $\begin{array}{l}\text { Ark., Miss., Mo., Texas, La., } \\
\text { Puerto Rico }\end{array}$ \\
\hline LL604 & Long & Not approved & Not approved & $\begin{array}{l}\text { Ark., Miss., Mo., Texas, La., } \\
\text { Puerto Rico }\end{array}$ \\
\hline \multicolumn{5}{|c|}{$\begin{array}{l}\text { * Includes Food and Drug Adminstration, Environmental Protection Agency and U.S. Department of Agriculture Animal and Plant Health } \\
\text { Inspection Service. Federal approval does not automatically entail approval at the state level. }\end{array}$} \\
\hline
\end{tabular}

\title{
Biosafety or trade barrier? Japan's tenuous trade with California
}

\begin{abstract}
Tapan is the California rice industry's largest international customer, purchasing more than $\$ 421$ million in 2009 - over $40 \%$ of the industry's exports (FAS 2010). If tests on imports find transgenic traits, Japan has suggested that it would deny rice shipments. Some observers question whether such policies are about biosafety or if they constitute a barrier to trade.
\end{abstract}

Rice is culturally, religiously and politically significant in Japan. Japan has invoked national food-security policies that promote self-sufficiency and smallholder paddy production (OhnukiTierney 1993); nonetheless, it is a leading food importer, deriving about $40 \%$ of its total calories from imports (Sato 2007). Like California, Japan produces temperate, medium-grain japonica varieties. In Japan, however, per-acre production costs are 10 or more times higher, and consumer prices are two to three times higher than in California (Fukuda et al. 2003). Post-World War II land reforms divided rice-growing areas into holdings of less than 7 acres. In contrast with other food commodities, Japan is self-sufficient in rice production and tends to guard its domestic rice markets against imports.

During the 1994 Uruguay Round of international trade negotiations, Japan yielded to U.S. pressure and agreed to phase out rice import restrictions, reduce government subsidies and annually increase the amount of rice it imported. Japan is required to import more than 680,000 tons of rice per year (Fukuda et al. 2003). About 100,000 tons of this rice is used in food and beverage manufacturing; the rest is directed to government warehouses for eventual re-exportation as foreign food aid (Fukuda et al. 2003). In 2006, Japan announced that

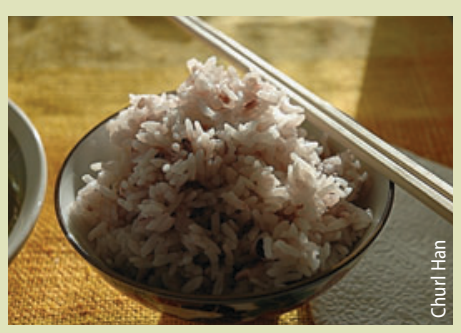
Turkey and South Korea, maintain rice import protocols similar to those of Japan. Both Taiwan and South Korea also have Uruguay Round commitments that are contradictory to the interests of domestic the rice surpluses stored in government warehouses would also be used for biofuels (Annon 2006), and production commenced in 2009 (Takada 2009).

Japan's strict policies on transgenic rice are rooted in both concerns about biosafety and economic protectionism. The Cartagena Protocol on Biosafety part of the United Nations Convention on Biodiversity - allows countries to base decisions about transgenic organisms on the precautionary principle. When risks from biotechnologies are severe and potentially irreversible, nations can implement labeling and other regulatory requirements. Codex Alimentarius, the international standards-setting organization for food safety, has developed guidelines for food derived from biotechnology (i.e., transgenic foods) and suggests labeling as an appropriate approach to risk management (Codex 2003). Both institutions seek to ensure that restrictions on trade are not rooted in protectionism and are informed by the best available information about food safety and environmental consequences.

Unfortunately for California rice growers, other foreign customers that also import japonica rice, such as Taiwan, rice farmers in those countries, and both have asserted strict import restrictions on transgenic rice. Turkey banned transgenic rice altogether. While it is difficult to determine whether protectionism, culture or biosafety are the main forces driving such policies, all play a role in influencing the deployment of transgenic rice.

$$
\begin{aligned}
& \text { - D.R. Mulvaney, T.J. Krupnik, } \\
& \text { K.B. Koffler }
\end{aligned}
$$

\section{References}

Annon A. 2006. Stockpiled import rice to be used in biofuel. Asahi Shimbun. www.asahi.com/english/Heraldasahi/TKY200611140179.html (accessed Feb. 27, 2008).

[Codex] Codex Alimentarius. Foods Derived From Biotechnology. ftp://ftp.fao.org/codex/Publications/Booklets/ Biotech/Biotech_2003e.pdf (accessed Dec. 5, 2010). [FAS] Foreign Agricultural Service. 2010. Global Agricultural Trade System Online. US Department of Agriculture. Wash., DC. www.fas.usda.gov/gats (accessed Dec. 7, 2010).

Fukuda H, Dyck J, Stout J. 2003. Rice Sector Policies in Japan. Electronic Outlook Report. US Department of Agriculture, Economic Research Service. Washington, DC. RCS-0303-01.

Ohnuki-Tierney E. 1993. Rice as Self: Japanese Identities Through Time. Princeton, NJ: Princeton Univ Pr. 184 p. Sato S. 2007. Japan Biotechnology Annual Report. Global Agriculture Information Network Rep JA7040. US Department of Agriculture, Foreign Agricultural Service. Washington, DC.

Takada A. 2009. Japan sake brewer to begin biofuel output from imported rice. Bloomberg News. http:// checkbiotech.org/node/25683 (accessed Nov. 1, 2009). 